\title{
Immigranten vlak na migratie en de verandering in de houding ten aanzien van homoseksualiteit
}

\author{
Bulgaren, Polen, Marokkanen, Turken, Antillianen en Surinamers in \\ Nederland
}

Dirk-Jan Janssen \& Marcel Lubbers

MEM 91 (1): 5-26

DOI: 10.5117/MEM2016.1.JANS

\begin{abstract}
Summary
Immigrants right after migration and the change in attitude towards homosexuality

In this study we investigate the changes in the attitude towards homosexuality among immigrants to the Netherlands in the first years after migration. We test possible explanations for an attitude change related to dynamics in integration in the Netherlands: the extent to which social contact, media use and church attendance are associated to changes in attitudes towards homosexuality. We used the NORFACE funded Dutch panel data 'Causes and Consequences of Social and Cultural Integration Process among recent immigrants to Europe' (SCIP). Bulgarian, Polish, Moroccan, Turkish, Antillean and Surinamese immigrants are included in this study. An unexpected finding is that recent immigrants generally became more negative regarding homosexuality during their stay in the Netherlands. There is quite some betweenand within-migrant group variation: the Bulgarians have become more positive in contrast to the other migrant groups. Watching Dutch television and a decline in church attendance have a positive effect on the change in attitude towards homosexuality. The increase in church attendance can explain why immigrants, in general, became more negative. No support was found for the expected impact of changes in social contact.
\end{abstract}

Keywords: immigrants, homosexuality, attitude change, integration, Netherlands 


\section{$1 \quad$ Inleiding}

Deze studie richt zich op de houding van nieuwe immigranten in Nederland uit verschillende landen ten aanzien van homoseksualiteit en onderzoekt of deze houding verandert kort na migratie. Eerdere studies hebben aangetoond dat de bevolking van West-Europese landen, en Nederland in het bijzonder, nogal verschilt van de bevolking uit andere landen in de houding ten aanzien van homoseksualiteit. Dat werd de afgelopen jaren ook weer duidelijk in de internationale betrekkingen zoals tussen Rusland en Nederland, toen uitgerekend in het jaar dat Rusland en Nederland 400 jaar betrekkingen vierden, in Rusland een wet tegen zogenaamde homoseksuele propaganda werd aangenomen, waarna demonstraties in Nederland volgden. Bovendien liep de spanning verder op nadat een homoseksuele, Nederlandse diplomaat in Moskou was mishandeld (Van den Dool, 2013). Ook in de relatie tussen Nederland en Turkije speelde het standpunt over homoseksualiteit een rol, omdat commotie ontstond over het beroep dat Turkse Nederlanders deden op de Turkse overheid toen de voogdij over hun kinderen werd overgedragen aan een lesbisch stel (Van Berkel, 2013).

Uit Europees vergelijkend onderzoek blijkt dat Nederland tolerant is ten aanzien van homoseksualiteit, dit in tegenstelling tot Oost-Europese landen. De Europese landen waarin homoseksualiteit het minst geaccepteerd wordt, zijn vooral Oost-Europese landen zoals Polen, Roemenië en Litouwen (Stulhofer \& Rimac, 2009; Van den Akker, Van de Ploeg \& Scheepers, 2013). Recentelijk hebben Kuyper, Iedema en Keuzenkamp (2013) trends in homoacceptatie gepresenteerd. In vrijwel alle West-Europese landen is het aandeel van de bevolking dat negatief staat tegenover homoseksualiteit sterk afgenomen. Maar deze verandering heeft zich niet of nauwelijks voorgedaan in Oost-Europa. Het contrast tussen Nederland en Oost-Europese landen in de publieke opinie over homoseksualiteit is daarmee aanzienlijk. Onderzoek heeft uitgewezen dat de publieke opinie van veel West-Europese landen niet slechts afwijkt van die in Oost-Europese landen, maar ook van die in andere (vooral niet-westerse) landen (Adamczyk \& Pitt, 2009).

De laatste jaren is er een sterke toename geweest van migratie uit OostEuropa (Rijksoverheid, 2013), naast de migratie uit meer traditionele herkomstlanden als Turkije, Marokko, Suriname en de Antillen. De vragen die wij hier opwerpen zijn of immigranten die uit een land komen waar de publieke opinie over homoseksualiteit zo anders is dan in Nederland, veranderen in hun houding tegenover homoseksualiteit in de eerste jaren dat zij in Nederland woonachtig zijn, en in hoeverre deze verandering verklaard kan worden. Met de aandacht voor deze veranderingen willen we 
meer inzicht bieden in welke mate blootstelling aan een andere publieke opinie nieuwkomers beïnvloedt, en welke kenmerken dit versterken. Door rekening te houden met de context van de migratiegroep en de mate waarin men blootgesteld is aan de Nederlandse context biedt deze studie de mogelijkheid rekening te houden met verschillende normatieve contexten. Ook voor beleidsmakers is het relevant om kennis te hebben over het al dan niet veranderen van de houding zonder ingrijpen van de overheid. Ook $\mathrm{nu}$, in 2015, met de toename van het aantal vluchtelingen, is het relevant om te kunnen vaststellen wat verblijf in Nederland betekent voor de houding ten aanzien van homoseksualiteit (Volkskrant, 2015). De onderzoeksvragen van deze bijdrage luiden: In welke mate verandert de houding ten aanzien van homoseksualiteit onder migranten in de eerste jaren van hun verblijf in Nederland?; en: In welke mate wordt de veranderende houding ten aanzien van homoseksualiteit verklaard door blootstelling aan de Nederlandse samenleving?

Het huidige onderzoek richt zich op de veranderende houding ten aanzien van homoseksualiteit onder immigranten in Nederland in de periode vlak na migratie. Dat is in eerder onderzoek nog niet gedaan. In het onderzoek van het Sociaal en Cultureel Planbureau is de acceptatie van homoseksualiteit onder allochtonen onderzocht (Keuzenkamp, 2011). Vergeleken met autochtone Nederlanders accepteren allochtonen homoseksualiteit minder. In eerder onderzoek is al naar voren gekomen dat deze verschillen deels te verklaren zijn door verschillen in bevolkingskenmerken, zoals een gemiddeld lager opleidingsniveau en een groter belang van religie onder allochtone groepen in vergelijking met autochtonen. Dat onderzoek heeft de Marokkanen, Turken, Antillianen en Surinamers in Nederland bestudeerd, maar niet de recente immigranten uit deze betreffende landen en evenmin immigranten uit Oost-Europa. Er is evenmin onderzocht, in hoeverre de houding van immigranten verandert. In dit onderzoek bestuderen we de veranderende houding ten aanzien van homoseksualiteit onder Bulgaren en Polen, alsook onder migranten uit de grootste etnische groepen (Marokkanen, Turken, Antillianen en Surinamers) die recentelijk naar Nederland zijn gemigreerd.

Voor het beantwoorden van de onderzoeksvragen wordt gebruik gemaakt van het databestand Causes and Consequences of Social and Cultural Integration Process among Recent Immigrants to Europe (SCIP). Dit bestand bevat gegevens over verschillende nieuwe immigranten in Nederland. De immigranten hebben zich in 2009 of 2010 als nieuwe inwoner van Nederland laten registreren in de Gemeentelijke Basisadministratie, hebben deelgenomen aan het onderzoek in 2010/2011, en hebben een tweede keer deelgenomen in 2012/2013. 


\section{Theorie}

De algemene hypothese die we hier opstellen is dat blootstelling aan een positiever opinieklimaat tegenover homoseksualiteit invloed heeft op de houding hierover en een stimulus zal zijn voor een verandering in de richting van de meer tolerante houding.

In het onderzoek naar de verandering van sociale houdingen (aangaande gelijkheid voor vrouwen, abortus, homoseksualiteit en Afro-Amerikanen) van Russische immigranten in de Verenigde Staten van Goldenberg en Saxe (1996) worden twee contrasterende hypothesen geformuleerd, namelijk op basis van het persistence model en het life-long openness model. In het eerste model wordt er vanuit gegaan dat sociale houdingen worden gevormd in de kindertijd. Deze houding wordt voornamelijk van ouder op kind doorgegeven. Wanneer het individu volwassen is, zou er nog maar weinig aan deze sociale houding veranderen. In het tweede model wordt verondersteld dat de ervaringen uit de kindertijd een kleinere invloed hebben op de sociale houding die men op volwassen leeftijd heeft. Het huidige sociale milieu zou juist een grotere invloed hebben. Uit de resultaten blijkt dat immigranten een negatievere houding hebben ten aanzien van homoseksualiteit dan autochtonen. Een deel van de migranten veranderde echter hun houding naar de algemene publieke opinie, die minder negatief was dan onder de migranten. Hoewel een minderheid veranderde, nemen Goldberg en Saxe op basis van hun bevindingen het life-long openness model aan. Door het aannemen van dit model lijkt men tevens de bevestiging te vinden dat de houding afhangt van de context; mensen zouden geneigd zijn hun houding aan te passen in de richting van wat de meerderheid vindt. Ook uit het onderzoek van Kilmnick (2006) blijkt dat de houding verandert na blootstelling aan een andere context, hoewel hij dit onderzoekt op een ander niveau dan Goldberg en Saxe. Kilmnick onderzoekt in hoeverre de houding ten aanzien van homoseksualiteit verandert (onder heteroseksuele studenten) nadat zij in contact waren gekomen met een openlijk homoseksuele instructeur in de collegezaal. Uit de resultaten van dit onderzoek blijkt dat het contact met de homoseksuele instructeur de negatieve attitudes onder de heteroseksuele studenten vermindert. Dit is in overeenstemming met andere studies over de invloed van contact met homo's op hetero's (Pettigrew and Tropp, 2006). Aan de hand van deze conclusies stellen we de verwachting op dat de houding ten aanzien van homoseksualiteit, onder immigranten, positiever wordt naarmate zij langer in Nederland verblijven (hypothese 1).

Hoewel migranten in Nederland allemaal blootgesteld staan aan de Nederlandse publieke opinie, kan men zich in meerdere of mindere mate 
blootstellen aan die Nederlandse norm. Migranten kunnen zich sterker gaan richten op de Nederlandse samenleving, maar men kan zich ook sterk blijven richten op de eigen etnische groep en daardoor juist weinig in contact komen met mensen of instituties die blijk geven van een tolerante norm over homoseksualiteit. Deze gerichtheid van migranten op Nederland of het land van herkomst wordt door Berry (1997) wel aangeduid als een acculturatiestrategie. Als men zich blootstelt aan de Nederlandse samenleving, is er sprake van integratie of assimilatie. Wanneer men zich juist afzijdig houdt van de Nederlandse samenleving, is er sprake van separatie of marginalisatie. Immigranten kunnen zelf bepalen in welke mate men zich blootstelt aan de Nederlandse samenleving. Belangrijke indicatoren voor acculturatiestrategieën zijn mediagebruik en sociale contacten, waarin de immigranten kunnen verschillen in de mate van contact met autochtone Nederlanders en met mensen uit het land van herkomst, en in de mate van gebruik van Nederlandse media en media van het land van herkomst. De acculturatiestrategie bepaalt in welke mate men zich blootstelt aan deze indicatoren. Het kan namelijk zijn dat de immigrant nog de media gebruikt uit het land van herkomst en sociale contacten onderhoudt met mensen uit de eigen groep. Daarnaast kan in het seculiere Nederland het vasthouden aan de religie uit het land van herkomst gezien worden als een activiteit die acculturatie in de weg staat. In de komende paragrafen worden daarom hypothesen geformuleerd die rekening houden met verschillen tussen immigranten en met de mate waarin ze blootgesteld worden aan de Nederlandse norm.

\subsection{Sociaal contact}

We veronderstellen dat migranten die in sterkere mate contacten zijn aangegaan met autochtone Nederlanders meer meekrijgen van het opinieklimaat in Nederland. De omgang met autochtonen zorgt voor blootstelling aan andere normen en waarden (Tartakovsky, 2012), waaronder blootstelling aan normen en waarden ten aanzien van homoseksualiteit. Migranten zouden door het contact met de autochtonen hun houding ten aanzien van homoseksualiteit kunnen herzien en de meer tolerante normen en waarden ten aanzien van homoseksualiteit overnemen van de autochtone Nederlanders. Hoe de causaliteit hier werkt is echter ongewis. Het zou namelijk ook zo kunnen zijn dat mensen met een positievere houding meer contact zoeken met autochtone Nederlanders. We kunnen hier echter wel onderzoeken of migranten die meer contact hebben met autochtonen net na migratie, vervolgens sterker zijn veranderd. We onderscheiden daarom twee hypothesen: Naarmate migranten net na migratie 
meer contact hebben met autochtonen, wordt hun houding ten aanzien van homoseksualiteit toleranter (2a); en: Naarmate migranten meer contact krijgen met autochtonen, is er een sterkere verandering naar een meer tolerante houding ten aanzien van homoseksualiteit $(2 b)$.

De blootstelling aan de Nederlandse, meer tolerante publieke opinie zal niet voor alle migranten even sterk zijn. Zoals in de algemene verwachting is aangegeven, verwachten we ook dat de contacten met de eigen etnische groep van invloed zijn op de houding ten aanzien van homoseksualiteit. Immigranten die veel contact hebben met de eigen etnische groep, worden blootgesteld aan de normen en waarden ten aanzien van homoseksualiteit binnen deze groep. De verwachting is dat deze normen en waarden over het algemeen negatiever zullen zijn ten aanzien van homoseksualiteit dan die onder autochtone Nederlanders. Migranten zullen daarom minder veranderen, of bij intensivering van de contacten wellicht minder tolerant worden. De hypothesen luiden dan ook: Naarmate migranten net na migratie meer contact hebben binnen de eigen etnische groep, verandert hun houding ten aanzien van homoseksualiteit minder naar een tolerante houding (3a); en: Naarmate migranten meer contact krijgen binnen de eigen etnische groep, is er een minder sterke verandering naar een meer tolerante houding ten aanzien van homoseksualiteit $(3 b)$.

\subsection{Mediagebruik}

Een andere vorm van blootstelling aan de publieke opinie in Nederland is via de media. Volgens de Uses and Gratification Theory (Blumler, 1974) hangt het mediagebruik af van behoeften en wensen die mensen hebben. Deze behoeften en wensen spelen een rol in de mate waarin zij kiezen voor Nederlandse media of gebruik maken van media uit het land van herkomst (of wellicht een derde land). De Nederlandse media weerspiegelen de Nederlandse normen en waarden, en de media uit het land van herkomst weerspiegelen de normen en waarden uit het land van herkomst. Doordat de normen en waarden van Nederland toleranter zijn ten aanzien van homoseksualiteit dan de landen vanwaar de migranten afkomstig zijn, zullen de Nederlandse media een positiever beeld geven van homo's dan media uit andere landen (Stulhofer \& Rimac, 2009).

Calzo en Ward (2009) hebben een onderzoek uitgevoerd naar de invloed van de blootstelling aan media en de houding ten aanzien van homoseksualiteit. Volgens hen spelen de media een belangrijke rol in het socialisatieproces van de houding. In de resultaten komt naar voren dat het bekijken van videoclips en televisiedrama's en het lezen van populaire tijdschriften een positieve invloed hebben op de houding. Dit is ook gevonden in onder- 
zoek van Wright (2011). Er is hier echter ook sprake van een causaliteitsprobleem. Het zou namelijk ook zo kunnen zijn dat mensen met een positievere houding vaker deze programma's bekijken. In een ander onderzoek (Riggle, 1996) is de attitude ten aanzien van homoseksualiteit gemeten onder een relatief kleine groep studenten (82), voor en na het kijken naar een documentaire over Harvey Milk. Milk was een homoseksuele politicus, die is vermoord vanwege zijn geaardheid. De onderzoekers vonden dat de houding positief was veranderd na het kijken van de documentaire. Mazur en Emmers-Sommers (2002) vonden dit ook toen zij dit experiment hadden herhaald. In lijn met dit idee van blootstelling aan media formuleren we de hypothesen: Naarmate migranten net na migratie vaker naar Nederlandse televisieprogramma's kijken, wordt hun houding ten aanzien van homoseksualiteit toleranter (4a); en: Naarmate migranten vaker naar Nederlandse televisieprogramma's zijn gaan kijken, is er een sterkere verandering naar een meer tolerante houding ten aanzien van homoseksualiteit $(4 b)$.

De verwachting is tevens dat het kijken naar zenders uit het land van herkomst van invloed is op de houding ten aanzien van homoseksualiteit. Immigranten die veel naar zenders uit het land van herkomst kijken, worden blootgesteld aan de normen en waarden ten aanzien van homoseksualiteit uit het land van herkomst. De verwachting is dat deze normen en waarden over het algemeen negatiever zullen zijn in het land van herkomst dan in Nederland. We formuleren daarom de volgende hypothesen over het volgen van media uit het land van herkomst: Naarmate migranten net na migratie vaker naar televisieprogramma's uit het land van herkomst kijken, verandert hun houding ten aanzien van homoseksualiteit minder naar een tolerante houding (5a); en: Naarmate migranten meer naar televisieprogramma's uit het land van herkomst zijn gaan kijken, is er een minder sterke verandering naar een meer tolerante houding ten aanzien van homoseksualiteit (5b).

\subsection{Religie}

Tot slot stellen we een verwachting op over de invloed van religie. Uit veel onderzoeken blijkt dat religie een van de sterkste voorspellers is van een negatieve houding ten aanzien van homoseksualiteit (Lubbers, Jaspers \& Ultee, 2009). Recentelijk heeft Hakhverdian (2013) op basis van gegevens van de European Election Study laten zien dat religie samenhangt met het afwijzen van het homohuwelijk. Niet-gelovigen bleken het meest progressief te zijn en moslims het meest conservatief. Katholieken, protestanten en orthodox-christelijken zitten qua houding ten aanzien van homoseksualiteit tussen niet-gelovigen en moslims in (Hakhverdian, 2013). Daarom 
is de verwachting dat veranderingen in kerkgang invloed hebben op de veranderende houding ten aanzien van homoseksualiteit.

Van Tubergen (2013) heeft laten zien dat in de eerste jaren na migratie kerk- dan wel moskeebezoek beduidend minder plaatsvindt dan voor migratie het geval was. Een verminderde blootstelling aan de religieuze boodschap vlak na migratie gaat wellicht gepaard met een minder strikte nadruk op de religieuze normen. Anderzijds kan verwacht worden dat met langer verblijf migranten hun weg weten te vinden naar kerken en moskeeën en juist weer sterker worden blootgesteld aan religieuze normen. Bovendien wordt wel gesteld dat wanneer mensen zich in grotere mate onzeker voelen, zij sterker religieus worden (Immerzeel \& Van Tubergen, 2009). Nieuwe immigranten kunnen zich in de eerste periode na de immigratie onzeker voelen doordat ze in een nieuw land zijn. Ze kennen de gebruiken niet, spreken de taal niet en hebben er weinig bekenden wonen. Een verwachting is dat migranten daardoor meer waarde gaan hechten aan religie. Ze gaan zich daarmee ook sterker hechten aan de traditionele normen en waarden van het geloof, met als gevolg dat traditionele opvattingen over bijvoorbeeld homoseksualiteit juist sterker worden. We onderzoeken of de migranten die vaker naar de kerk of moskee zijn gegaan ook negatiever zijn geworden over homoseksualiteit en of de migranten die minder naar de kerk of moskee zijn gegaan positiever zijn geworden. We stellen als laatste hypothesen op: Naarmate migranten net na migratie minder de kerk of moskee bezoeken, wordt hun houding ten aanzien van homoseksualiteit toleranter (6a); en: Naarmate migranten over de tijd steeds minder de kerk of moskee bezoeken, is er een sterkere verandering naar een meer tolerante houding ten aanzien van homoseksualiteit (6b).

\section{$3 \quad$ Data en operationalisering}

Om de geformuleerde hypothesen te toetsen wordt er gebruik gemaakt van de eerste twee waves van het SCIP project: Causes and Consequences of SocioCultural Integration Processes among New Immigrants in Europe (Diehl et al. 2015). Dit databestand bevat gegevens over onder andere de migratie, sociale netwerken, religie, culturele identiteit, het opleidingsniveau en de sociaaleconomische posities van de immigranten. De eerste wave van dit panelbestand is verzameld in 2010/2011, en dezelfde immigranten zijn gemiddeld na 15 maanden (in 2012/2013) weer benaderd. Door gebruik te maken van deze gegevens kan getoetst worden of de houding ten aanzien van homoseksualiteit is veranderd. De immigranten zijn geselecteerd op basis van het land van 
herkomst. Zo zijn recente immigranten meegenomen afkomstig uit Bulgarije, Polen, Marokko, Turkije, de Nederlandse Antillen, Aruba en Suriname. Door gegevens van de gemeenten weet men wanneer de immigranten zich hebben ingeschreven binnen die gemeenten. Alleen immigranten die bij de steekproeftrekking 12 maanden of minder in de Gemeentelijke Basisadministratie waren geregistreerd zaten in de random steekproef. Het zou echter kunnen dat mensen al wel langer dan 12 maanden in Nederland woonden, maar zich pas later hebben ingeschreven bij de gemeente. Deze respondenten zijn wel opgenomen in de dataset. De interviews zijn afgenomen in hun moedertaal. De gegevens zijn in de eerste en in de tweede wave verzameld door middel van face-to-face interviews. In de eerste wave van het onderzoek varieerde de respons tussen $34 \%$ onder de Marokkaanse migranten en $66 \%$ onder de Turkse migranten. In de tweede benadering heeft van alle wave 1-respondenten gemiddeld $45 \%$ opnieuw meegewerkt aan een tweede interview (onder de $55 \%$ non-respons is een groot deel toe te schrijven aan terugkeermigratie $(13 \%)$ en weigering aan het eind van wave 1 om nog een keer benaderd te worden (16\%)). Analyses op selectieve drop-out laten zien dat studenten vaker waren teruggekeerd, maar dat lager opgeleiden vaker weigerden aan een tweede wave mee te werken of minder goed bereikbaar waren in de tweede wave. Onder Polen viel het op dat de drop-out significant hoger was onder mannen dan onder vrouwen. Onder Marokkaanse en Antilliaanse migranten was de drop-out tussen de twee waves groter onder werklozen, terwijl dat niet het geval was onder de andere vier groepen (Gressner \& Schacht, 2015).

Het panelbestand (respondenten die aan wave 1 en 2 mee hebben deelgenomen) bestaat uit 1518 respondenten. Na het bewerken van de data en het weglaten van respondenten met ontbrekende waarden, houden we nog 1320 respondenten over om te analyseren.

\subsection{Afhankelijke variabele: tolerante houding ten aanzien van homoseksualiteit}

De afhankelijke variabele is gemeten door middel van de stelling: Homoseksuele mannen en lesbische vrouwen moeten vrij zijn om hun leven te leiden zoals zij dat willen. De antwoordcategorieën waren: (1) 'volstrekt mee eens', (2) 'mee eens', (3) 'mee eens noch oneens', (4) 'oneens', (5) 'volstrekt mee oneens'. Ten eerste is de vraag zo gecodeerd dat een hogere score betekent dat men het sterker eens is met deze stelling en dus positiever is ten aanzien van homoseksualiteit. Daarna is de waarde van wave 2 verminderd met de waarde van wave 1 . Wanneer de waarde positief is, dan is de houding ten aanzien van homoseksualiteit van de immigrant positiever geworden. Wanneer de immigrant een negatieve score heeft, dan is de 
houding negatiever geworden. Wanneer de immigrant de waarde o heeft, dan is de houding niet veranderd. In de analyses wordt de houding van wave 1 meegenomen als predictor, vanwege de mogelijke plafond- en bodemeffecten. Respondenten met de hoogste score tijdens wave 1 konden niet positiever worden en respondenten met de laagste score tijdens wave 1 konden niet negatiever worden. In totaal waren er 105 respondenten met een ontbrekende waarde op de afhankelijke variabele $(6,9 \%)$. Deze respondenten zijn niet mee genomen in de analyses.

\subsection{Onafhankelijke variabelen}

Verblijfsduur (in maanden) in Nederland is gemeten door middel van de vraag: 'Wanneer bent u naar Nederland verhuisd?'. Vervolgens is het aantal maanden tussen de genoemde maand en de maand waarin het interview is afgenomen berekend.

De mate van contact is gemeten met twee vragen: 'Hoe vaak brengt $u$ tijd door met Nederlanders?' en 'Hoe vaak brengt u tijd door met mensen uit het land van herkomst?'. De antwoordcategorieën waren: (1) 'elke dag', (2) 'enkele malen per week', (3) 'enkele malen per maand', (4) 'enkele keren per jaar', (5) 'minder vaak', (6) 'nooit'. Er is voor gekozen om zowel het contact met de autochtonen als het contact met de eigen groep mee te nemen, omdat een afname in het contact met mensen uit de eigen etnische groep niet automatisch betekent dat de immigrant meer contact heeft met autochtonen. Ook deze antwoordcategorieën zijn zo gecodeerd dat een hogere score betekent dat men meer contact heeft. Om de verandering te meten is voor beide items de waarde van wave 2 verminderd met de waarde van wave 1. Een positieve waarde betekent dat een immigrant meer contact heeft gekregen met deze groep. Een negatieve waarde betekent dat men minder contact heeft gekregen. De waarde o betekent dat de immigrant niet is veranderd.

Om het effect van blootstelling aan de Nederlandse televisie of televisie uit het land van herkomst te onderzoeken, is er gebruik gemaakt van twee vragen: 'Hoe vaak kijkt u naar televisie op Nederlandse kanalen?' en: 'Hoe vaak kijkt u televisie via kanalen uit het land van herkomst?'. De antwoordcategorieën waren: (1) 'elke dag', (2) 'enkele malen per week', (3) 'eenmaal of tweemaal per week', (4) 'minder vaak', (5) 'nooit'. Ten eerste zijn de antwoordcategorieën zo gecodeerd dat een hogere score betekent dat de respondent meer televisie kijkt. Om de verandering te meten is voor beide items de waarde van wave 2 verminderd met de waarde van wave 1 . Respondenten met een positieve waarde zijn meer naar de respectievelijke zenders gaan 
kijken. Respondenten met een negatieve score zijn minder naar deze zenders gaan kijken. De waarde o betekent dat de immigrant niet is veranderd.

Kerk- en moskeebezoek in Nederland en de verandering daarin zijn gemeten door middel van de vraag: 'Hoe vaak hebt u religieuze erediensten bijgewoond (behalve doop-, huwelijks- of begrafenisplechtigheden) sinds $u$ naar Nederland verhuisde?'. De antwoordcategorieën waren: (1) 'meer dan één keer per week', (2) 'eenmaal per week', (3) 'eenmaal per maand', (4) 'alleen op specifieke heilige dagen', (5) 'eenmaal per jaar', (6) 'minder vaak', (7) 'nooit of praktisch nooit'. Een deel van de respondenten is bij deze vraag gefilterd. Dat komt omdat ze eerder hebben aangegeven niet religieus te zijn. Er wordt er vanuit gegaan dat deze respondenten 'nooit of praktisch nooit' de kerk of moskee bezoeken. Ten eerste zijn de antwoordcategorieën zo gecodeerd dat een hogere score betekent dat men vaker naar de kerk of moskee gaat. Om de verandering te meten is de waarde van wave 2 verminderd met de waarde van wave 1 . Wanneer de waarde van deze verandering positief is, dan betekent dat deze respondent vaker naar de kerk of moskee is gegaan. Wanneer de respondent een negatieve waarde heeft, dan betekent dat hij minder vaak de kerk of moskee heeft bezocht. De waarde o betekent dat de immigrant niet is veranderd. In totaal waren er 93 respondenten met een ontbrekende waarde op ten minste één onafhankelijke variabele $(6,13 \%)$. Hiervan hadden 79 respondenten een ontbrekende waarde op de variabele kerk- en moskeebezoek ('weet niet' of 'wil niet zeggen'). Deze 93 respondenten zijn niet meegenomen in de analyses.

\subsection{Controlevariabelen}

In dit onderzoek wordt ook een aantal controlevariabelen meegenomen, omdat verwacht wordt dat er verschillen zullen zijn in de veranderende houding tussen verschillende migrantengroepen, opleidingsniveaus, jongeren en ouderen en mannen en vrouwen.

Zoals aangegeven maken we onderscheid naar de herkomst van de migranten. Er is een onderscheid gemaakt tussen Bulgaren, Polen, Marokkanen, Turken, Antillianen en Surinamers.

Het opleidingsniveau van de respondent is gemeten door middel van de vraag: 'Hoeveel jaar opleiding hebt $u$ in totaal voltooid?'. De immigranten konden zelf invullen hoeveel jaren opleiding ze hebben genoten. Immigranten die aan hebben gegeven geen opleiding te hebben gevolgd, zijn beschouwd als 'o jaren opleiding'. De ontbrekende waarden die toen overbleven, zijn vervangen door het gemiddelde aantal jaren opleiding per etnische groep. In totaal is bij 23 respondenten $(1,52 \%)$ de waarde vervan- 
gen door het gemiddelde. Respondenten die hebben aangeven meer dan 24 jaar onderwijs te hebben gevolgd, zijn samengevoegd tot één groep: (24) 'meer dan 24 jaar onderwijs gevolgd'. Uit de lineariteitstest bleek dat deze variabele nog steeds lineair opgenomen kon worden.

Tevens zijn de leeftijd en het geslacht $(\operatorname{man}=0)($ vrouw=1) van de immigranten meegenomen. De leeftijd van de immigrant tijdens wave 1 wordt gebruikt.

\section{Resultaten}

In Tabel 1 wordt een overzicht gegeven van de beschrijvende statistiek. In Tabel 1 is te zien dat de houding ten aanzien van homoseksualiteit negatiever is geworden in wave 2 ten opzichte van wave 1 . Op een schaal van o-4 zijn de immigranten gemiddeld een halve punt negatiever geworden. Uit de t-toets blijkt dit verschil ook significant te zijn. Dit is niet in lijn met de verwachting. De verwachting was namelijk dat de houding ten aanzien van homoseksualiteit positiever zou zijn tijdens de tweede meting, naarmate de recente immigranten langer in Nederland zouden verblijven. In Appendix 1 is de houding ten aanzien van homoseksualiteit op meting 1 en 2 weergegeven, uitgesplitst voor de verschillende migrantengroepen. De verschillen tussen beide metingen zijn wederom met een t-toets getoetst. Hieruit kwam naar voren dat de Polen niet significant zijn veranderd. De Bulgaren zijn significant toleranter geworden ten aanzien van homoseksualiteit. De andere etnische groepen zijn daarentegen significant minder tolerant geworden ten aanzien van homoseksualiteit.

Uit Tabel 1 kan ook worden opgemaakt dat respondenten minder contact hebben gekregen met autochtone Nederlanders. Uit de t-toets blijkt deze afname significant. De immigranten geven tevens aan dat ze minder contact hebben gekregen met mensen uit de eigen etnische groep. Deze afname is eveneens significant. De verandering in het kijken naar de Nederlandse televisie en naar de zenders uit het land van herkomst is niet significant. De immigranten gaan echter wel vaker naar de kerk of moskee in wave 2 ten opzichte van wave 1 . Deze toename is significant. 
Tabel 1 Beschrijvende gegevens

\begin{tabular}{|c|c|c|c|c|}
\hline & $\begin{array}{l}\text { Gemid- } \\
\text { delde }\end{array}$ & Std. Dev. & Min. & Max. \\
\hline \multicolumn{5}{|c|}{ Tolerante houding ten aanzien van homoseksualiteit } \\
\hline Houding wave 1 & 2,455 & 1,113 & 0 & 4 \\
\hline Houding wave 2 & 2,007 & 1,202 & 0 & 4 \\
\hline Verandering in houding & $-0,449$ & 1,347 & -4 & 4 \\
\hline Verblijfsduur & 14,399 & 10,731 & 0 & 53 \\
\hline \multicolumn{5}{|l|}{ Contact Nederland } \\
\hline Contact Nederland wave 1 & 3,567 & 1,779 & 0 & 5 \\
\hline Contact Nederland wave 2 & 3,014 & 1,857 & 0 & 5 \\
\hline Verandering in Contact Nederland & $-0,552$ & 2,255 & -5 & 5 \\
\hline \multicolumn{5}{|l|}{ Contact Herkomst } \\
\hline Contact Herkomst wave 1 & 4,371 & 1,190 & 0 & 5 \\
\hline Contact Herkomst wave 2 & 4,187 & 1,178 & 0 & 5 \\
\hline Verandering in Contact Herkomst & $-0,186$ & 1,618 & -5 & 5 \\
\hline \multicolumn{5}{|l|}{ Televisiekijken Nederland } \\
\hline Televisiekijken Nederland wave 1 & 2,291 & 1,574 & 0 & 4 \\
\hline Televisiekijken Nederland wave 2 & 2,226 & 1,500 & 0 & 4 \\
\hline Verandering in televisiekijken Nederland & $-0,066$ & 1,641 & -4 & 4 \\
\hline \multicolumn{5}{|l|}{ Televisiekijken Herkomst } \\
\hline Televisiekijken Herkomst wave 1 & 2,412 & 1,763 & 0 & 4 \\
\hline Televisiekijken Herkomst wave 2 & 2,466 & 1,745 & 0 & 4 \\
\hline Verandering in televisiekijken Herkomst & 0,054 & 1,441 & -4 & 4 \\
\hline \multicolumn{5}{|l|}{ Kerkgang } \\
\hline Kerkgang wave 1 & 2,236 & 2,059 & 0 & 6 \\
\hline Kerkgang wave 2 & 2,892 & 1,913 & 0 & 6 \\
\hline Verandering in Kerkgang & 0,656 & 2,187 & -6 & 6 \\
\hline \multicolumn{5}{|l|}{ Etniciteit } \\
\hline Bulgaren & 0,109 & - & 0 & 1 \\
\hline Polen (ref.) & 0,253 & - & 0 & 1 \\
\hline Marokkanen & 0,067 & - & 0 & 1 \\
\hline Turken & 0,317 & - & 0 & 1 \\
\hline Antillianen & 0,121 & - & 0 & 1 \\
\hline Surinamers & 0,134 & - & 0 & 1 \\
\hline Opleidingsniveau & 11,059 & 4,746 & 0 & 24 \\
\hline Leeftijd & 31,767 & 9,553 & 19 & 67 \\
\hline Geslacht (ref.=man) & 0,531 & - & 0 & 1 \\
\hline
\end{tabular}


Door middel van een lineaire-regressieanalyse zijn de hypotheses getoetst. In Tabel 2 worden de resultaten van deze analyses weergeven. In Model 1 worden alleen de controlevariabelen opgenomen, de houding ten aanzien van homoseksualiteit op wave 1, en verblijfsduur. Het aantal maanden dat de migrant in Nederland is heeft geen invloed op de veranderende houding ten aanzien van homoseksualiteit. Behalve dat we vonden dat de houding in wave 2 negatiever is dan in wave 1, vinden we in dit model evenmin bewijs voor een verandering naar een positievere houding bij langer verblijf in $\mathrm{Ne}$ derland. Er wordt daarom geen ondersteuning gevonden voor de eerste hypothese. Het model laat ook zien dat migranten die al positief waren, het minst kunnen veranderen in positieve richting (plafond-effect), wat de reden is voor het negatieve effect van de houding ten aanzien van homoseksualiteit op wave 1 . In Model 2 voegen we de predictoren waarover we onze overige hypothesen hebben opgesteld toe: contact met Nederlanders, contact met leden van de herkomstgroep, Nederlandse televisie kijken, televisie uit het land van herkomst kijken, en kerk- of moskeebezoek. We voegen zowel de situatie van wave 1 toe als de verandering tussen wave 1 en wave 2.

In Model 2 is te zien dat contact tussen immigranten en autochtone Nederlanders een positief significant effect heeft op de veranderende houding van immigranten ten aanzien van homoseksualiteit $(\mathrm{p}=0,016)$. Dit is in lijn met de verwachting waarmee hypothese 2a wordt ondersteund. Het contact met mensen uit de herkomstgroep blijkt geen effect te hebben op de verandering naar een tolerante houding $(\mathrm{p}=0,187)$. Daarom wordt hypothese za niet ondersteund. De veranderingen in contact met autochtone Nederlanders of met de eigen etnische groep blijken geen effect te hebben op de veranderende houding ten aanzien van homoseksualiteit $(\mathrm{p}=0,086$; $\mathrm{p}=0,592$ ). Daarmee worden zowel hypothese $2 \mathrm{~b}$ als hypothese $3 \mathrm{~b}$ niet ondersteund.

Hoe meer immigranten kort na aankomst in Nederland naar de Nederlandse televisie keken, des te meer kregen zij een positievere houding ten aanzien van homoseksualiteit. Dit effect is significant $(p=0,003)$. Dit is in lijn met de verwachting en daarom wordt hypothese 4a bevestigd. Het kijken naar de zenders uit het land van herkomst blijkt niet van invloed te zijn op de verandering in houding ten aanzien van homoseksualiteit $(\mathrm{p}=0,737)$. Hypothese 5 a wordt daarom niet aangenomen. Het meer gaan kijken naar de Nederlandse televisie heeft ook een positief, significant effect op de veranderende houding ten aanzien van homoseksualiteit $(\mathrm{p}=0,002)$. Daarmee wordt hypothese $4 \mathrm{~b}$ bevestigd. Het meer gaan kijken naar zenders uit het land van herkomst blijkt niet van invloed te zijn op de veranderende houding $(\mathrm{p}=0,485)$. Hypothese $5 \mathrm{~b}$ wordt daarom ook niet ondersteund. 
De houding ten aanzien van homoseksualiteit is negatiever geworden onder immigranten die veel naar de kerk of moskee gingen $(p=0,000)$. Ook heeft een toename van het bezoeken van de kerk of moskee een negatief, significant effect op de verandering $(\mathrm{p}=0,000)$. Daarom wordt zowel hypothese $6 \mathrm{a}$ als hypothese $6 \mathrm{~b}$ ondersteund.

De modellen laten tevens zien dat er grote verschillen zijn tussen de migrantengroepen. Zo zijn de Antillianen, de Surinamers, de Marokkanen en de Turken significant negatiever geworden ten aanzien van homoseksualiteit ten opzichte van de verandering die de Polen hebben doorgemaakt. Bulgaren zijn daarentegen significant positiever geworden ten aanzien van homoseksualiteit ten opzichte van de Polen. De ontwikkelingen die we reeds bij de verschillende migrantengroepen hebben gezien (Appendix 1), blijven dus bestaan als er gecontroleerd wordt voor de verschillende acculturatiestrategieën. Daarnaast is er sprake van een significant opleidingseffect. Hoe hoger men is opgeleid, des te positiever is de veranderende houding ten aanzien van homoseksualiteit $(p=0,034)$. Men zou verwachten dat het effect van opleiding verklaard zou worden wanneer verschillende vormen van contact, televisie kijken en kerk- en moskeebezoek zijn opgenomen in het model, maar dit is niet het geval. Het positieve, significante effect van opleiding bestaat naast de effecten van contact, media en religie. Ook zijn vrouwen significant positiever geworden ten aanzien van homoseksualiteit dan mannen. Het effect van leeftijd is niet significant.

In Appendix 2 is weergegeven welke bevindingen uit Model 2 gelden voor elk van de zes migrantengroepen. Onder de Polen en de Turken heeft meer kerk- dan wel moskeebezoek het verwachte negatieve effect op de verandering naar een meer tolerante houding ten aanzien van homoseksualiteit. Onder de Antillianen en Surinamers heeft contact met autochtonen een significant positief effect en contact met de eigen groep een significant negatief effect op de veranderende houding ten aanzien van homoseksualiteit. Ook wanneer Surinamers meer naar Nederlandse televisiezenders gaan kijken, worden zij significant positiever. Bulgaren veranderen significant negatief ten aanzien van homoseksualiteit wanneer ze meer naar zenders uit het land van herkomst gaan kijken en ze worden (opvallend) significant positiever naarmate ze meer contact hebben met andere Bulgaren. Een verklaring hiervoor zou kunnen zijn dat Bulgaren over het algemeen positief veranderen; dus naarmate het contact met andere Bulgaren toeneemt, veranderen zij positiever. Onder de Marokkanen heeft meer contact met autochtone Nederlanders een significant positief effect op de veranderende houding ten aanzien van homoseksualiteit. 
Tabel 2 Lineaire regressie van de Verandering naar een meer tolerante houding ten aanzien van homoseksualiteit

\begin{tabular}{|c|c|c|c|c|}
\hline & $\begin{array}{c}\text { Model } 1 \\
\text { B-coëfficiënt }\end{array}$ & S.E. & $\begin{array}{l}\text { Model } 2 \text { B- } \\
\text { coëfficiënt }\end{array}$ & S.E. \\
\hline \multicolumn{5}{|l|}{ Onafhankelijke variabelen (W1) } \\
\hline Houding wave 1 (gecentreerd) & $-0,921^{* * *}$ & 0,022 & $-0,936^{* * *}$ & 0,022 \\
\hline Contact Nederland & & & $0,048^{*}$ & 0,020 \\
\hline Contact Herkomst & & & $-0,039$ & 0,029 \\
\hline TV Nederland & & & $0,065^{* *}$ & 0,022 \\
\hline TV Herkomst & & & 0,007 & 0,022 \\
\hline Kerkgang & & & $-0,057^{* * *}$ & 0,015 \\
\hline Verblijfsduur & 0,003 & 0,003 & 0,003 & 0,003 \\
\hline \multicolumn{5}{|l|}{ Verandering (W2-W1) } \\
\hline$\Delta$ Contact Nederland & & & 0,025 & 0,015 \\
\hline$\Delta$ Contact Herkomst & & & $-0,012$ & 0,022 \\
\hline$\Delta$ TV Nederland & & & $0,058^{* *}$ & 0,019 \\
\hline$\Delta$ TV Herkomst & & & 0,014 & 0,020 \\
\hline$\Delta$ Kerkgang & & & $-0,059^{* * *}$ & 0,014 \\
\hline \multicolumn{5}{|l|}{ Controlevariabelen } \\
\hline Bulgaren & $0,993^{* * *}$ & 0,094 & $0,981^{* * *}$ & 0,097 \\
\hline Polen & Ref. & Ref. & Ref. & Ref. \\
\hline Marokkanen & $-0,597^{* * *}$ & 0,112 & $-0,513^{* * *}$ & 0,127 \\
\hline Turken & $-1,494^{* * *}$ & 0,077 & $-1,401^{* * *}$ & 0,083 \\
\hline Antillianen & $-0,937^{* * *}$ & 0,091 & $-1,009^{* * *}$ & 0,108 \\
\hline Surinamers & $-1,139^{* * *}$ & 0,086 & $-1,235^{* * *}$ & 0,103 \\
\hline Opleidingsniveau & $0,014^{*}$ & 0,005 & $0,011^{*}$ & 0,005 \\
\hline Leeftijd & $-0,003$ & 0,002 & $-0,001$ & 0,002 \\
\hline Geslacht (ref.=man) & $0,239^{* * *}$ & 0,046 & $0,215^{* * *}$ & 0,046 \\
\hline Constante & $-0,022$ & 0,148 & $-0,026$ & 0,200 \\
\hline$R^{2}$ & 0,636 & & 0,648 & \\
\hline
\end{tabular}




\section{$5 \quad$ Conclusie en discussie}

Binnen Europa zijn er grote verschillen in de publieke opinie ten aanzien van homoseksualiteit. Onderzoek heeft aangetoond dat Nederlanders relatief tolerant zijn ten aanzien van homoseksualiteit. Daarentegen is men in Oost-Europese landen, net als in de landen waar de vier grootste migrantengroepen in Nederland vandaan komen, vaker negatief ten aanzien van homoseksualiteit. Met de komst van nieuwe immigranten uit minder tolerante landen ten aanzien van homoseksualiteit rijst de vraag in hoeverre hun houding verandert ten aanzien van homoseksualiteit tijdens de eerste jaren na hun migratie naar Nederland. Een verklaring voor de mogelijke verandering is in dit onderzoek gezocht in de blootstelling aan normen over homoseksualiteit die anders zijn dan die in het land van herkomst. Daartoe hebben we onderzocht in hoeverre verblijfsduur, sociale contacten, mediagebruik en kerkgang en veranderingen daarin samenhangen met een verandering in de houding ten aanzien van homoseksualiteit.

Uit de resultaten komt naar voren dat immigranten tijdens de tweede benadering wat negatiever waren ten aanzien van homoseksualiteit dan in de eerste benadering. We vonden bovendien geen relatie tussen verblijfsduur en veranderingen in de houding ten aanzien van homoseksualiteit. Verklaringen voor het negatiever worden over homoseksualiteit vinden we in de sterkere mate van blootstelling aan religieuze waarden en normen, doordat het kerk- en moskeebezoek een aantal jaar na migratie hoger ligt dan in de eerste periode direct na migratie. We vinden dat kerk- of moskeebezoek en een toename hiervan tussen wave 1 en wave 2 samengaan met het negatiever worden van de houdingen tegenover homoseksualiteit. Ook vinden we een daling in de mate van contact tussen de immigranten en autochtone Nederlanders tussen wave 1 en wave 2, maar deze verandering blijkt niet samen te hangen met de verandering in de houding ten aanzien van homoseksualiteit. Immigranten die al meer contact hadden met autochtone Nederlanders tijdens wave 1 hebben een meer positieve houding gekregen ten aanzien van homoseksualiteit. Het is overigens opmerkelijk dat de mate van contact afgenomen is. Wellicht ligt de verklaring voor deze daling in de manier hoe contact is gemeten. Het gaat namelijk om een algemene contactmeting. Een immigrant ziet net na migratie wellicht elke vorm van contact nog als noemenswaardig contact, terwijl bij langer verblijf alleen sterkere vormen van contact worden gerapporteerd. Voor het huidige onderzoek is het bovendien een gemis dat geen informatie beschikbaar is over het contact met homo's en lesbiennes in Nederland. Het is interessant om te bezien in hoeverre contacten met deze groep ontstaan en van invloed zijn op de houding. 
Het kijken naar de Nederlandse televisie en een toename daarvan blijken positief samen te hangen met een verandering naar een meer tolerante houding ten aanzien van homoseksualiteit. Hieruit kunnen we concluderen dat kerk en de media een socialiserende werking hebben, en dat het life-long openness model, het uitgangspunt over veranderende houdingen gedurende de levensloop, ook hier wordt ondersteund (Goldenberg \& Saxe). Houdingen over homoseksualiteit blijken te veranderen door blootstelling aan verschillende sociale omgevingen.

Een beperking van het onderzoek is dat de tijd tussen beide metingen relatief kort is. Tussen beide metingen zitten gemiddeld 15 maanden. Toch zagen we wel veranderingen in deze periode. Een mogelijke verklaring voor het negatiever worden van de houding ten aanzien van homoseksualiteit kan zijn, dat na een kort verblijf in Nederland de Nederlandse normen en waarden als botsend met en provocerend tegenover de cultuur uit het land van herkomst worden ervaren. Wellicht dat immigranten hierdoor zich juist sterker bewust worden van de publieke opinie waarin zij zijn gesocialiseerd en deze sterker naar voren laten komen in het onderzoek. Wellicht dat we daarmee meer een vorm van verandering in de realisatie van het verschil tussen de publieke opinie van Nederland en die uit het land van herkomst hebben gemeten, in plaats van een daadwerkelijke verandering in de houding. Het is vanzelfsprekend interessant om dezelfde groep mensen te onderzoeken over een langere periode. Zullen de immigranten alsnog toleranter worden ten aanzien van homoseksualiteit? Daarnaast is het relevant te noemen dat er verschillen zijn tussen verschillende migrantengroepen. Zo werden de Bulgaren juist positiever over langere tijd, de Polen veranderden gemiddeld genomen niet en de vier niet-westerse migrantengroepen (recente migranten uit Turkije, Marokko, Suriname en van de Antillen) werden minder tolerant. Een mogelijke verklaring voor de uitzonderingspositie onder de Bulgaren is dat de kerkgang onder Bulgaren al laag was in Bulgarije in vergelijking met bijvoorbeeld de Polen in Polen (Gijsberts \& Lubbers, 2013). Dit zou kunnen verklaren waarom hun houding net na migratie het meest tolerant was en waarom zij ook veranderden naar een meer tolerante houding.

Het model dat we hier vinden geeft voorzichtige steun aan de rol van kennismaking en blootstelling aan de Nederlandse normen bij de verandering naar een meer positieve houding ten aanzien van homoseksualiteit, ook al werden de immigranten in dit onderzoek over het algemeen wat minder tolerant ten aanzien van homoseksualiteit tijdens hun eerste verblijf in Nederland. Vooral de blootstelling aan specifieke contexten bleken tot verandering te leiden. Dit inzicht is niet alleen relevant voor de recente 
migranten die naar Nederland zijn verhuisd, maar ook voor vluchtelingen die naar Nederland zijn gekomen.

\section{Appendix 1: Tolerante houding ten aanzien van homoseksualiteit (per etnische groep)}

\begin{tabular}{|c|c|c|c|c|}
\hline & Gemiddelde & Std. Dev. & Min. & Max. \\
\hline \multicolumn{5}{|l|}{ Bulgaren ( $N=144)$} \\
\hline Houding wave 1 & 3,090 & 0,836 & 0 & 4 \\
\hline Houding wave 2 & 3,681 & 0,763 & 0 & 4 \\
\hline Verandering in houding & 0,590 & 1,143 & -4 & 4 \\
\hline \multicolumn{5}{|l|}{ Polen $(\mathrm{N}=334)$} \\
\hline Houding wave 1 & 2,874 & 1,009 & 0 & 4 \\
\hline Houding wave 2 & 2,790 & 0,823 & 0 & 4 \\
\hline Verandering in houding & $-0,084$ & 1,136 & -3 & 4 \\
\hline \multicolumn{5}{|l|}{ Marokkanen $(\mathrm{N}=88)$} \\
\hline Houding wave 1 & 2,364 & 0,873 & 0 & 4 \\
\hline Houding wave 2 & 2,000 & 0,661 & 0 & 4 \\
\hline Verandering in houding & $-0,364$ & 1,030 & -3 & 3 \\
\hline \multicolumn{5}{|l|}{ Turken $(\mathrm{N}=418)$} \\
\hline Houding wave 1 & 1,990 & 1,134 & 0 & 4 \\
\hline Houding wave 2 & 1,101 & 0,792 & 0 & 4 \\
\hline Verandering in houding & $-0,890$ & 1,342 & -4 & 3 \\
\hline \multicolumn{5}{|l|}{ Antillianen $(N=159)$} \\
\hline Houding wave 1 & 2,384 & 1,084 & 0 & 4 \\
\hline Houding wave 2 & 1,742 & 0,963 & 0 & 4 \\
\hline Verandering in houding & $-0,642$ & 1,407 & -3 & 3 \\
\hline \multicolumn{5}{|l|}{ Surinamers $(\mathrm{N}=177)$} \\
\hline Houding wave 1 & 2,356 & 1,057 & 0 & 4 \\
\hline Houding wave 2 & 1,548 & 0,929 & 0 & 4 \\
\hline Verandering in houding & $-0,808$ & 1,326 & -4 & 2 \\
\hline
\end{tabular}




\begin{tabular}{|c|c|c|c|c|}
\hline 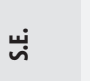 & 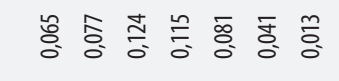 & ⿳ㅗㅇ응영 영 영 & 壱 兑 $\frac{\dddot{m}}{0}$ & 愛 \\
\hline 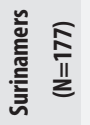 & 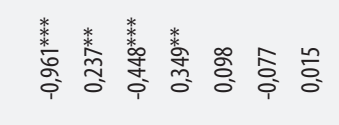 & 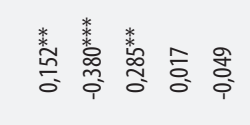 & 兽 & 퉁 융: \\
\hline نّ & 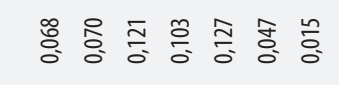 & 영응 영 & 홍 咅 $\frac{\wp}{0}$ & đa \\
\hline 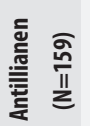 & 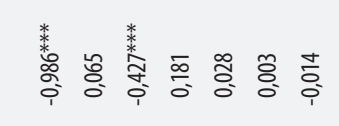 & 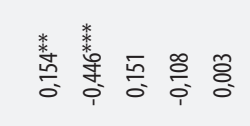 & 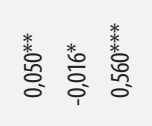 & 壳 \\
\hline نّ & 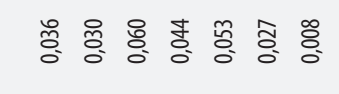 & 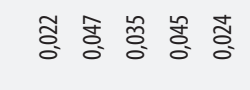 & 응 : 영 : & 裹 \\
\hline 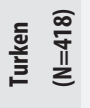 & 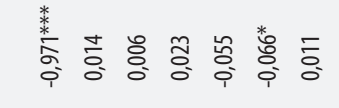 & 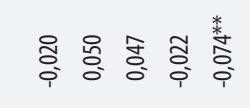 & 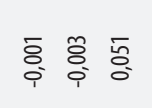 & 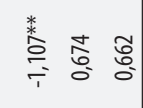 \\
\hline نّ & 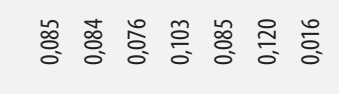 & 형 영 영 영 응 & 产 兽 & 号 \\
\hline 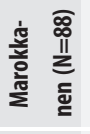 & 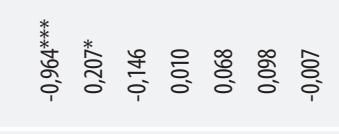 & 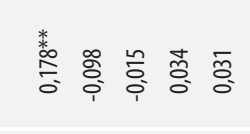 & 홍 훙 : & 旁总 \\
\hline نّ & 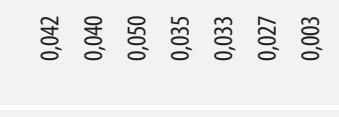 & 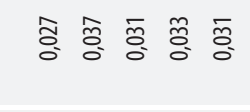 & 홍 응 영 & 兽 \\
\hline 这 & 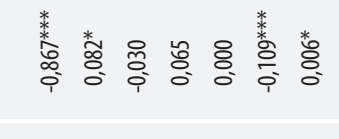 & 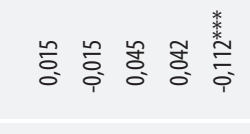 & 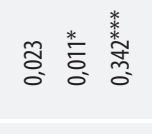 & 总总 \\
\hline$\ddot{~}$ & 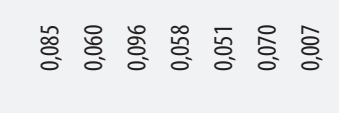 & 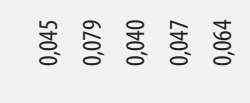 & 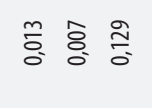 & $\underset{\infty}{\infty}$ \\
\hline 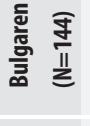 & 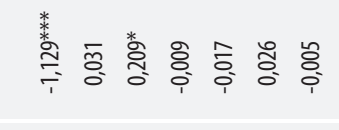 & 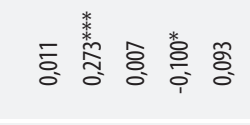 & 응 홍 홍 & $\underset{0}{0}$ \\
\hline & 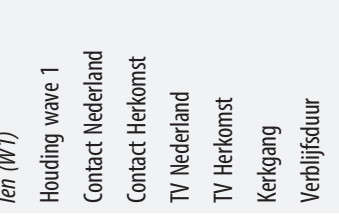 & 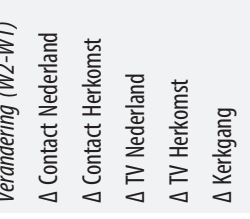 & 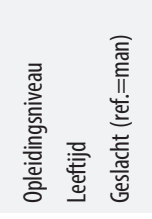 & 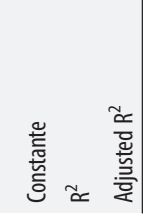 \\
\hline
\end{tabular}




\section{Referenties}

Adamczyk, A., \& Pitt. C. (2009). Shaping attitudes about homosexuality: The role of religion and cultural context. Social Science Research, 38(2), 338-351.

Berry, J. W. (1997). Immigration, acculturation, and adaptation. Applied psychology. 46(1), 5-34.

Blumler, J. G., Katz, E., \& Blumler, J. G. (1974). The uses of mass communications: Current perspectives on gratifications research (Vol. 3). Beverly Hills, CA: Sage publications.

Calzo, J. P., \& Ward, L. M. (2009). Media exposure and viewers' attitudes towards homosexuality: Evidence for mainstreaming or resonance? Journal of Broadcasting \& Electronic Media, 53(2), 280-299.

Diehl, C., Gijsberts, M., Güveli, A., Koenig, M., Kristen, C., Lubbers, M., McGinnity, F., Mühlau, P., Platt, L, and Van Tubergen, F. (2015): Socio-Cultural Integration Processes of New Immigrants in Europe (SCIP) - Data file for download. GESIS Data Archive, Cologne.

Gijsberts, M. I. L., \& Lubbers, M. (2013). Nieuw in Nederland. Het leven van recent gemigreerde Bulgaren en Polen. Den Haag: SCP.

Gresser, A. and Schacht, D. (2014). SCIP Survey Methodological Report. GESIS-Sowiport (URL: http://sowiport.gesis.org/search/id/gesis-sofis-oo114139/Description\#tabnav).

Goldenberg, V., \& Saxe, L. (1996). Social attitudes of Russian immigrants to the United States. The Journal of Social Psychology, 136(4), 421-434. doi:10.1080/00224545.1996.971402

Hakhverdian, A. (2013). Who's afraid of same-sex marriage? Verkregen via: http://stukroodvlees.nl/vertrouwen/whos-afraid-of-same-sex-marriage/.

Immerzeel, T., \& Van Tubergen, F. (2013). Religion as reassurance? Testing the insecurity theory in 26 European countries. European sociological review, 29(2), 359-372.

Kilmnick, D. (2006). Heterosexist attitudes: Changes following contact with an openly gay instructor. ProQuest, UMI Dissertations Publishing.

Keuzenkamp, S. (2011). Acceptatie van homoseksualiteit in Nederland 2011: internationale vergelijking, ontwikkelingen en actuele situatie. Sociaal en Cultureel Planbureau.

Kuyper, L., Iedema, J., Keuzenkamp, S. (2013) Exploring changes and explaining differences in attitudes towards homosexuality in Europe. Sociaal en Cultureel Planbureau.

Mazur, M., \& Emmers-Sommer, T. (2002). The effect of movie portrayals on audience attitudes about nontraditional families and sexual orientation. Journal of Homosexuality, 44(1), 157179.

Norris, P. and Inglehart, R. (2004). Sacred and secular: religion and politics worldwide. New York: Cambridge University Press.

Riggle, E., Ellis, A., \& Crawford, A. (1996). The impact of "media contact" on attitudes toward gay men. Journal of Homosexuality, 37(3), 55-69.

Rijksoverheid. (2013). Immigratie, integratie en asiel. Verkregen via http://www.rijksoverheid.nl.

Stulhofer, A., \& Rimac, I. (2009). Determinants of homonegativity in Europe. Journal of Sex Research, 46(1), 24-32.

Tartakovsky, E. (2012). Factors affecting immigrants' acculturation intentions: A theoretical model and its assessment among adolescent immigrants from Russia and Ukraine in Israel. International Journal of Intercultural Relations, 36(1), 83-99.

Ultee, W., Arts, W., \& Flap, H. (2003). Ongelijkheid. In W. Ultee, W. Arts \& H. Flap (Eds.), Sociologie vragen, uitspraken, bevindingen (pp. 69-70). Groningen: Martinus Nijhoff.

Van Berkel, M. (2013, 15 maart). Asscher: Turkije, bemoei je er niet mee! Spitsnieuws. Verkregen via: http://www.spitsnieuws.nl/archives/binnenland/2013/03/asscher-turkije-bemoei-je-erniet-mee.

Van den Dool, Pim (2013, 8 november). Omstreden bezoek koning aan Rusland. Wordt hij pion in 
conflict? NRC. Verkregen via: http://www.nrc.nl/nieuws/2013/11/o8/koning-vertrekt-vandaagnaar-rusland-4-vragen-over-zijn-omstreden-bezoek/.

Van Tubergen. F. (2013). Religious change of new immigrants in the Netherlands: the event of migration. Social Science Research, 42(3), 715-725.

Van den Akker, H., Van der Ploeg, R., \& Scheepers, P. (2013). Disapproval of homosexuality: Comparative research on individual and national determinants of disapproval of homosexuality in 20 European countries. International Journal of Public Opinion Research, 25(1), 6486.

Volkskrant. (2015, 2 november). Oktober: evenveel vluchtelingen naar Europa als in heel 2014. De Volkskrant. Verkregen via: http://www.volkskrant.nl/buitenland/oktober-evenveel-vluchtelingen-naar-europa-als-in-heel-jaar-2014 a4176473/

Wright, P. J. (2011). Mass media effects on youth sexual behavior: Assessing the claim for causality. Communication Yearbook, 35, 343-386.

\section{Over de auteurs}

Dirk-Jan Janssen is Research Master student en heeft in het kader van het disciplinaire honours-programma van de Radboud Universiteit dit onderzoek opgezet en uitgevoerd.

E-mail: dirk-jan.janssen@student.ru.nl

Marcel Lubbers is universitair hoofddocent sociologie aan de Radboud Universiteit. Thomas van Aquinostraat 6.01.17, 6525 GD Nijmegen.

E-mail: m.lubbers@maw.ru.nl 